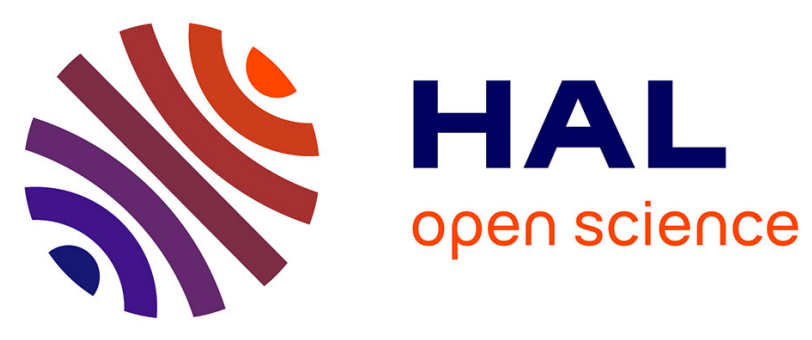

\title{
Corrosion processes of carbonated chloride-contaminated reinforced concrete and electrochemical chloride extraction (ECE) efficiency
}

Yolaine Tissier, Véronique Bouteiller, Elisabeth Marie Victoire, Suzanne Joiret, Thierry Chaussadent

\section{To cite this version:}

Yolaine Tissier, Véronique Bouteiller, Elisabeth Marie Victoire, Suzanne Joiret, Thierry Chaussadent. Corrosion processes of carbonated chloride-contaminated reinforced concrete and electrochemical chloride extraction (ECE) efficiency. 8th International RILEM PhD Workshop, Sep 2016, Marne-la-Vallée, France. pp 159-172, 10.1007/978-3-319-90236-4_12 . hal-03258625

\section{HAL Id: hal-03258625 \\ https://hal.science/hal-03258625}

Submitted on 11 Jun 2021

HAL is a multi-disciplinary open access archive for the deposit and dissemination of scientific research documents, whether they are published or not. The documents may come from teaching and research institutions in France or abroad, or from public or private research centers.
L'archive ouverte pluridisciplinaire HAL, est destinée au dépôt et à la diffusion de documents scientifiques de niveau recherche, publiés ou non, émanant des établissements d'enseignement et de recherche français ou étrangers, des laboratoires publics ou privés. 


\title{
Corrosion processes of carbonated chloride- contaminated reinforced concrete and electrochemical chloride extraction (ECE) efficiency
}

\author{
Yolaine Tissier ${ }^{1,2,3}$, Véronique Bouteiller ${ }^{1}$, Elisabeth Marie Victoire ${ }^{2}$, Suzanne \\ Joiret $^{3}$, Thierry Chaussadent ${ }^{4}$ \\ ${ }^{1}$ Université Paris-Est, MAST, SDOA, IFSTTAR, F-77447 Marne-la-Vallée, \\ France \\ ${ }^{2}$ Laboratoire de Recherche des Monuments Historiques, 77420 Champs sur Marne, \\ France \\ ${ }^{3}$ Université Pierre et Marie Curie, LISE, UMR 8235, CNRS, 75252 Paris Cedex \\ 05, France \\ ${ }^{4}$ Université Paris-Est, MAST, CPDM, IFSTTAR, F-77447 Marne-la-Vallée, \\ France
}

\begin{abstract}
Civil engineering structures and historical buildings can suffer from corrosion of the embedded reinforcing steel once the concrete cover is totally carbonated and/or when chloride ions have reached the steel/concrete interface. In practice, these two types of contamination can be encountered separately or combined requiring implementation of proper repair methods. In this research, carbonated and chloride-contaminated reinforced concrete specimens were studied by three main analysis means: electrochemical characterizations, Raman microspectrometry and scanning electron microscopy (SEM). The specimens were contaminated in a two-step process involving addition of chlorides followed by carbonation of the complete cover. Electrochemical chloride extraction (ECE) was then performed as a repair treatment $\left(1 \mathrm{~A} / \mathrm{m}^{2}\right.$ of steel surface during 8 weeks). The efficiency of the treatment and its impact on the steel/concrete interface and cement matrix were studied during the treatment, after steel depolarization and on the long term (several months) in order to evaluate the durability of the treatment. Electrochemical characterizations showed an increase of corrosion rates comparing the specimens after fabrication and after carbonation (from a negligible level of $0.1 \mu \mathrm{A} / \mathrm{cm}^{2}$ to values in excess of $10 \mu \mathrm{A} / \mathrm{cm}^{2}$ ). SEM observations confirmed this significant increase with the identification of a corrosion layer on most of the steel/concrete interface after carbonation. The ECE efficiency was evidenced by a decrease of chloride content below the practical threshold value of $0.4 \%$ by weight of cement after a two weeks treatment. Simultaneously a
\end{abstract}


realkalisation ring was observed around the reinforcement bar having a diameter of about $1 \mathrm{~cm}$ after four weeks. Results obtained after depolarization showed that a two weeks ECE treatment allowed the stabilization of the corrosion state of the rebar.

\section{Introduction}

Complete cover carbonation and chloride ions penetration until the steel/concrete interface are the two main causes of reinforcement corrosion that will lead to concrete degradation. These two types of contamination can be encountered separately or combined in civil engineering structures as well as in historical buildings requiring implementation of proper repair methods.

This paper aims to characterize the corrosion processes of reinforced concretes contaminated by chloride ions and carbonation prior and after repair using an electrochemical chloride extraction (ECE) treatment. For this purpose, four series of specimens were cast based on two cements and two aging processes.

In this paper, the study's complete protocol for a given series is presented (preliminary results can be found in the MSSCE 2016 conference [1]). Results obtained during the aging and during the treatment are presented and discussed. SEM-EDS analyses and Raman microspectrometry were used to characterize the corrosion products layer at the steel/concrete interface. SEM-EDS provided information on the distribution of corrosion products, morphology and elements of composition while Raman microspectrometry allowed the identification of crystallized corrosion phases formed. Electrochemical characterization (nondestructive-testing (NDT)) was used to follow the evolution of the rebar's corrosion state (active/passive) as well as the durability effect of the treatment.

\section{Methodology}

In this section the features of the specimens and the experimental program established to follow the evolution of the rebar's corrosion state during the aging and during the electrochemical treatment are presented.

\section{Specimens formulation and design}

Specimens were reinforced concrete cylinders of $10 \mathrm{~cm}$ in height and $4 \mathrm{~cm}$ in diameter (Figure 1). Composition as given in Table 1 was previously used in literature [2] in order to stay close to the granular distribution of a concrete on a micro-concrete scale. The 0.65 water/cement ratio was chosen to improve the chemical reactions within the concrete cover and was representative of old structures. 


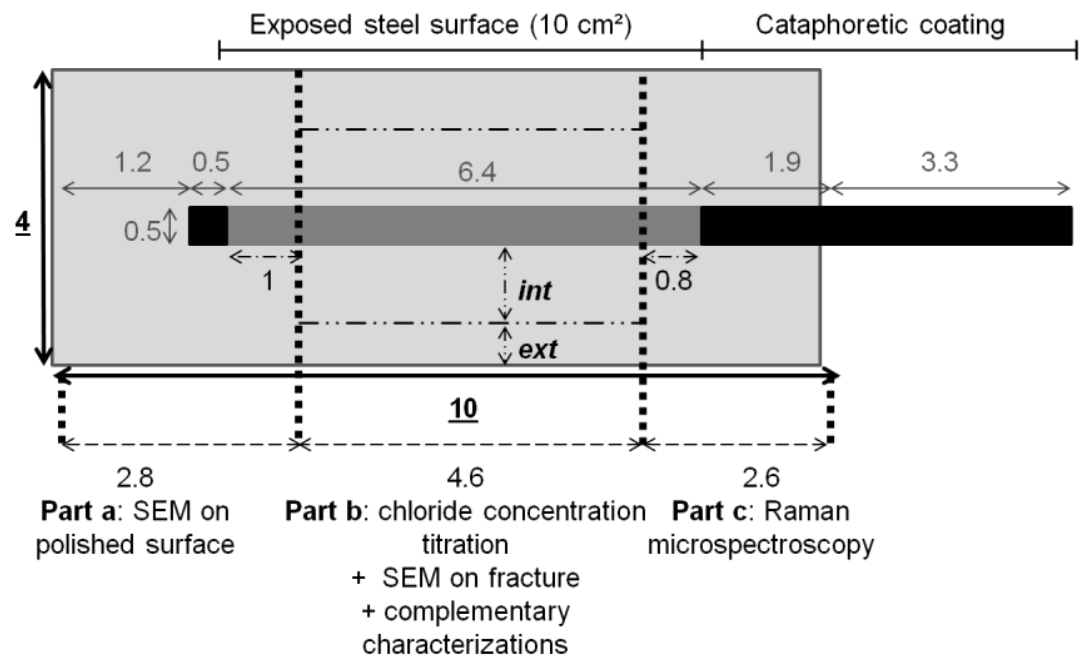

Figure 1. Specimens design (dimensions in $\mathrm{cm}$ ) and decomposition in three parts for the analytical characterizations.

\begin{tabular}{cccccccc}
\hline \multicolumn{2}{c}{ siliceous Palvadeau aggregates } & & $\begin{array}{c}\text { Cement } \\
\left(\mathbf{k g} / \mathbf{m}^{\mathbf{3}}\right)\end{array}$ & $\begin{array}{c}\text { Water } \\
\left(\mathbf{k g} / \mathbf{m}^{\mathbf{3}}\right)\end{array}$ & w/c ratio \\
$\left(\mathbf{k g} / \mathbf{m}^{3}\right)$ & \\
\hline $0 / 0.315$ & $0.315 / 1$ & $0.5 / 1$ & $1 / 4$ & $2 / 4$ & 387 & 251.55 & 0.65 \\
\hline 159 & 295 & 192 & 686 & 229 & 387 & & 0.55 \\
\hline
\end{tabular}

Table I. "Micro-concrete" composition.

Two types of cement were selected:

- CEM I (52.5 N CP2; Holcim, Lumbres factory) is a usual Portland cement which will allow comparisons with literature results. Specimens cast with CEM I cement were named type 1.

- CEM III/A (52.5 L PM ES CP1 NF; Lafarge, Le Havre factory), is a cement that has been frequently encountered in historical concrete monuments. Furthermore, this cement which contains blast furnace slag is promoted for the construction of new structures because of its lower impact on environmental issue (less $\mathrm{CO}_{2}$ production). Therefore, the results will help to improve the knowledge of reinforced structures using this cement. Specimens cast with CEM III/A cement were named type 3.

The water accessible porosity measured after curing ( 28 days for CEM I cement and 90 days for CEM III cement) was about $18 \% \pm 1 \%$. 
The rebar used was a pretreated (polished, cleaned, degreased) smooth round steel type $\mathrm{S} 235 \mathrm{JR}$ of $5 \mathrm{~mm}$ in diameter with an exposed surface area (in contact with the surrounding concrete) of $10 \mathrm{~cm}^{2}$.

\section{Experimental set-up}

A specific set-up was designed (Figure 2) in order to study, in a first step, the corrosion of steel embedded in a carbonated and chloride-contaminated concrete and, in a second step, to investigate the efficiency and impact of the electrochemical repair (during the treatment and after its end).

\begin{tabular}{|c|c|c|c|}
\hline \multicolumn{2}{|l|}{ Corrosion processes } & \multicolumn{2}{|c|}{ Treatment evaluation } \\
\hline Concrete fabrication & Carbonation & ECE treatment & Treatment durability \\
\hline $\begin{array}{l}\mathrm{Cl}^{-} \text {addition } \\
\text { To the } \operatorname{mix} \\
\text { (Type } \mathrm{G} \text { ) }\end{array}$ & $\begin{array}{c}\mathrm{Cl}^{-} \text {addition } \\
\text { By wetting/drying c } \\
\text { (Type I) }\end{array}$ & & \\
\hline
\end{tabular}

Figure 2. Experimental set-up.

Two different aging procedures were studied:

- Chloride addition to the fresh mix (5\% of $\mathrm{NaCl}$ by cement weight corresponding to a chloride content of $3 \%$ by cement weight) and then, after hardening, carbonation $\left(50 \% \quad \mathrm{CO}_{2} ; 70 \% \mathrm{RH}\right)$ until complete carbonation of the concrete cover. These aged specimens were named type $\mathrm{G}$.

- Carbonation until complete carbonation of the concrete cover $\left(50 \% \mathrm{CO}_{2}\right.$; $70 \% \mathrm{RH})$ followed by chloride penetration through consecutive wetting/drying cycles (five days submerged in a solution of $35 \mathrm{~g} / \mathrm{L} \mathrm{NaCl}$ followed by two days drying in the laboratory at room temperature and relative humidity). Specimens that were aged according to this procedure were named type I.

Colour indicators were used to determine the carbonated concrete thickness (phenolphthalein $(0.5 \%$ in ethanol $))$ and the chloride penetration $(0.1 \mathrm{~N}$ silver nitrate solution).

After the aging processes, the electrochemical chloride extraction treatment was conducted on 37 specimens of each series (G1, I1, G3 and I3). The set-up of the treatment is presented in Figure 3. Complying with the NF EN 14038 part 2 standard [3], a current density of $1 \mathrm{~A} / \mathrm{m}^{2}$ of steel was continually applied between the rebar and an external titanium/platinum grid (the counter-electrode was located around the specimens) during 8 weeks (Figure 3). Electrolyte was a disodium tetraborate solution $\left(25 \mathrm{~g} / \mathrm{L}\right.$ of $\left.\mathrm{Na}_{2} \mathrm{~B}_{4} \mathrm{O}_{7} 10 \mathrm{H}_{2} \mathrm{O}\right)$ which promotes alkaline buffering and chloride entrapment. ECE treatment monitoring relied on room temperature, 
applied current, voltages (each specimen and all the specimens) records on a one hour frequency base. After 3, 7, 14, 28 and 56 days of treatment, for each series, three control specimens were taken for analyses (Figure 1). These durations were selected as several authors observed that the extraction of chloride ions was more efficient at the beginning of the treatment [4-7]. The electrolyte was renewed at each of the 5 terms (except at 3 days) to avoid a loss of treatment efficiency due to the increase of chloride ions concentration into the electrolyte.

Regarding the chloride extraction evolution, both the free and total chloride concrete content were measured on two of the three specimens by $\mathrm{AgNO}_{3}$ potentiometric titration (at two locations: in the first centimetre around the rebar and in the $0.75 \mathrm{~cm}$ of external cover). Moreover the electrolyte chloride titration was also performed. Phenolphthalein test was performed on the surface of part $\mathrm{c}$ (Figure 1) of the same specimens. The third specimen was kept to perform an electrochemical characterization after depolarisation.

After treatment, the electrochemical characteristics of the reinforced specimens were checked every month to evaluate the depolarisation of the rebars (storage at $60 \% \mathrm{RH}$ and $20^{\circ} \mathrm{C}$ ) and the stability of the rebars' corrosion state. On a longer term, electrochemical characteristics were followed to ensure the treatment durability (the specimens were then exposed to a temperature of $20^{\circ} \mathrm{C}$ and cycles of relative humidity ( 1 week $92 \% \mathrm{RH} / 2$ weeks $60 \% \mathrm{RH})$.

Simultaneously to the treatment, two specimens were used to observe the occurrence of a lixiviation phenomenon. This was accomplished by immersing both specimens in the tetraborate solution, however without subjecting them to the current. After 28 days, $\mathrm{Cl}^{-}$content in concrete was analysed on one specimen. After 56 days, the corrosion of the rebar was examined by electrochemical measurements.

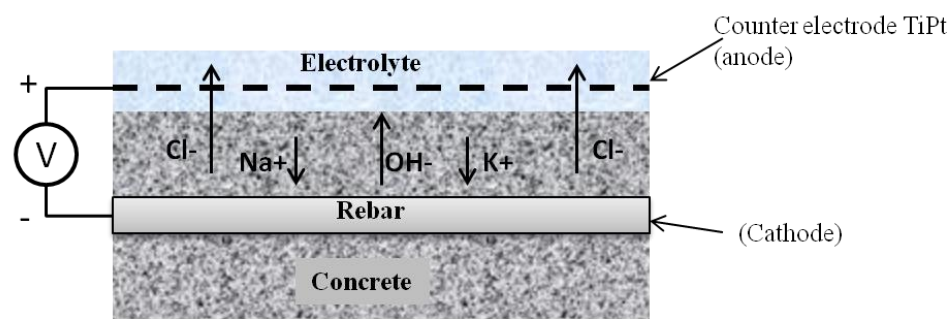

Figure 3. Set-up of electrochemical chloride extraction.

\section{Analysis means}

To study the corrosion processes of the rebar, three main analysis methods were used on different parts of the cylindrical specimen (Figure 1): 
- A Raman spectrometer (LABRAM from Jobin-Yvon Horiba) was used to determine the nature of the formed products. Spectra were obtained with a helium-neon red laser $(0.1 \mathrm{~mW})$. A x50 objective was used to focus laser light and collect spectra for a duration of 600 seconds. Specific designed cells were prepared to observe in-situ (steel/concrete interface isolated from a direct contact with the atmospheric oxygen) the corrosion processes during corrosion initiation, and during the ECE treatment.

After cutting part $\mathrm{c}$ as presented in Figure 1, a thin glass slide was pasted on the polished surface to prevent the transformation of the corrosion products induced by atmospheric oxygen. After preparation, these samples were immersed in a $25 \mathrm{~g} / \mathrm{L} \mathrm{Na} \mathrm{B}_{4} \mathrm{O}_{7} 10 \mathrm{H}_{2} \mathrm{O}$ solution. Frequently observations at a magnification of 50 were made until the detection of pitting corrosion. Raman spectra were then acquired in different areas of interest. The same areas were followed during the ECE treatment and after treatment.

- A scanning electron microscope (SEM JEOL 5600LV) equipped with a micro-analyzer $\mathrm{X}$ in dispersal of energy Oxford Link Pentaflet was used to observe corrosion at the concrete/steel interface. Two types of samples were examined: polished cross sections to evaluate corrosion layers evolution and fractured samples to observe both corrosion crystallised phases' morphology and eventual modifications of the cement matrix.

- Electrochemical characterizations were performed with a potentiostat (Bio-Logic, VMP2Z, 5 channels) at each step of the process. The half-cell potential $\left(\mathrm{E}_{\mathrm{corr}}\right)$, the linear polarization resistance $(\mathrm{LPR})$ and the electrical concrete resistance $(\mathrm{Re})$ were measured and the corrosion rate $\mathrm{i}_{\text {Corr }}$ $\left(\mu \mathrm{A} / \mathrm{cm}^{2}\right)$ was calculated according to Eq. (1).

$$
\mathrm{i}_{\text {Corr }}=\frac{B}{R_{p} S}
$$

With: $\mathrm{B}=26 \mathrm{mV}, \mathrm{R}_{\mathrm{p}}(\mathrm{ohm})$ the linear polarization resistance and $\mathrm{S}\left(\mathrm{cm}^{2}\right)$ the active steel surface $\left(10 \mathrm{~cm}^{2}\right.$ in this study)

This paper focuses on $\mathrm{G} 1$ specimens (CEM I cement, $\mathrm{NaCl}$ addition to the mix and carbonation). In the first part, corrosion processes are reported. In the second part the ECE treatment efficiency is demonstrated.

\section{Corrosion Processes}

\section{Corrosion products characterization}

Raman microspectrometry. Trials of corrosion followed in-situ were made with a G1 specimen before carbonation. Chlorinated green rust (Figure 4) was the predominant phase found (main Raman bands at $434 \mathrm{~cm}^{-1}$ and $506 \mathrm{~cm}^{-1}$ and a 
chloride presence characteristic band around $320 \mathrm{~cm}^{-1}$ ) [8] which evidenced the involvement of chloride into the corrosion processes. Moreover, green rust oxidation into FeIII oxyhydroxide did not occur which proved the good insulation of the interface from a direct exposure to oxygen from the air.

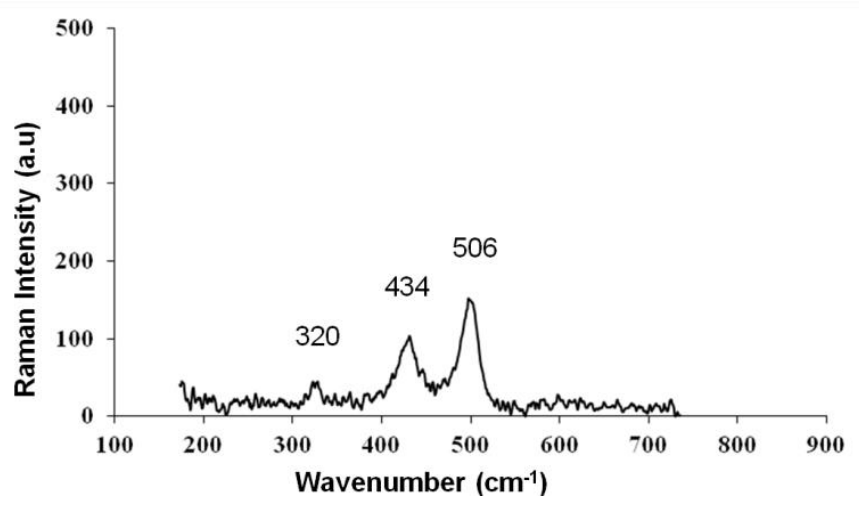

Figure 4. Chlorinated green rust Raman spectrum.

Scanning electron microscopy. After casting, the steel/concrete interface was mostly characterized by an absence of corrosion (Figure 5-a). Figure 5-b shows a representative area of the interface after carbonation with about $5 \mu \mathrm{m}$ of corrosion products on the steel and $5 \mu \mathrm{m}$ of migration within the concrete. After carbonation, the corrosion layer thickness could vary from 5 to $20 \mu \mathrm{m}$ and the penetration of corrosion products within the concrete was mostly of 5 to $15 \mu \mathrm{m}$. However on some localized areas a $250 \mu \mathrm{m}$ thickness was detected. The observation on fracture after carbonation (Figure 6-a) showed numerous areas of corrosion in the rebar imprint in concrete. Figure 6-b presents the crystallisation morphology of corrosion products mainly containing $\mathrm{Fe}, \mathrm{O}$ and $\mathrm{Cl}$. Figure 7 shows a representative result of EDS elemental analysis obtained on corrosion products which highlights the presence of chloride element. 

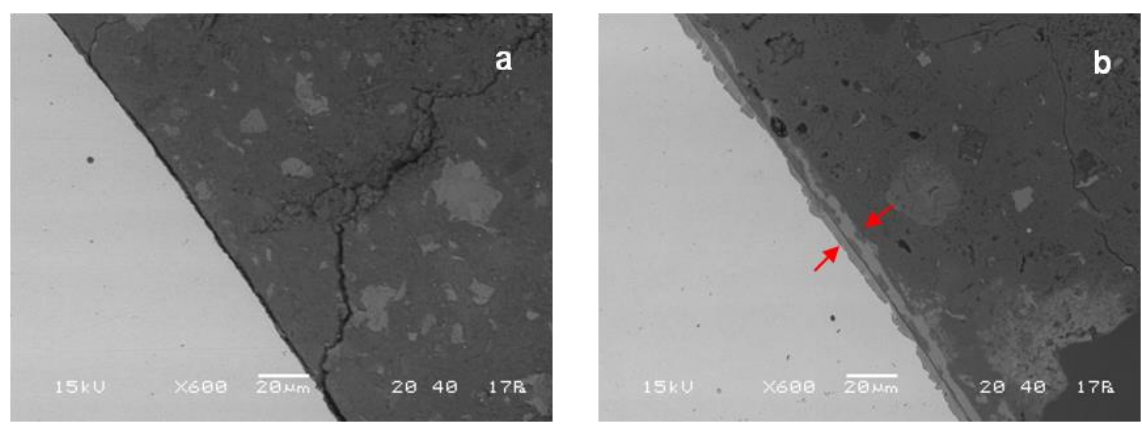

Figure 5. BEIC-SEM images (x600) of the steel/concrete interface on cross section of specimens type G1, (a) after casting without evidence of corrosion and (b) after carbonation with a thin layer of corrosion products.
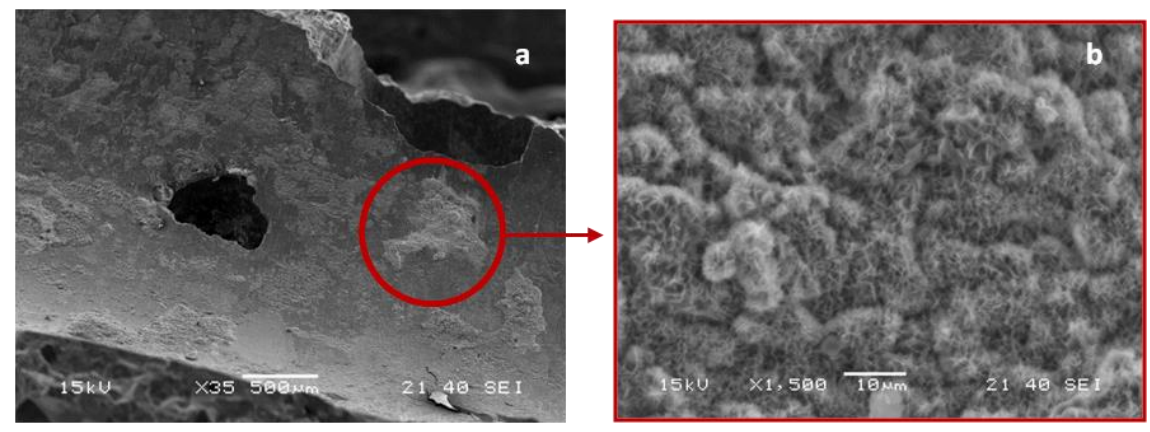

Figure 6. SEI-SEM images of corrosion products observed into the rebar imprint after carbonation (a) x35 and (b) x1500.

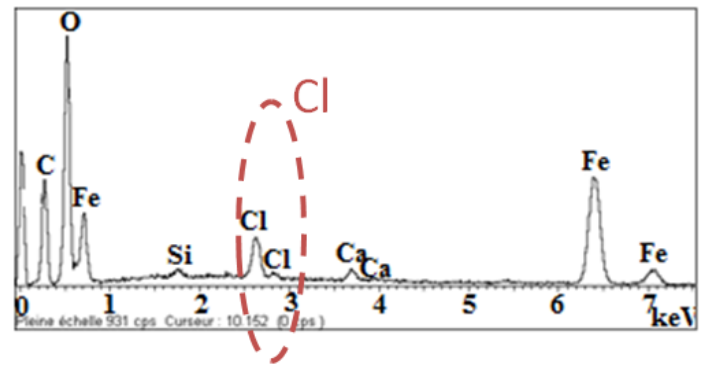

Figure 7. EDS elemental analysis of corrosion products after carbonation. 


\section{Electrochemical characterization}

Figure 8 presents the measurement results for the half-cell potential, the electrical resistance and the corrosion rate results at two different times. The first value (in light grey) is related to the corrosion state after curing ( 28 days curing +3 days) while the second value (in dark grey) is related to the corrosion state after carbonation (24 weeks after curing including a month of preconditioning and 14 weeks of accelerated carbonation). From Figure 8-a it can be deduced that G1 specimens potentials measured after curing ranged between $-230 \mathrm{mV}$ and $-579 \mathrm{mV}$ with a mean value of $-457 \mathrm{mV}$ and a standard deviation (based on the 70 specimens) of $84 \mathrm{mV}$ while after carbonation, the average value and the standard deviation were $-550 \mathrm{mV}$ and $14 \mathrm{mV}$, respectively (based on 57 specimens). This indicates that after carbonation, the potential values of the specimens rebar became more electronegative and showed less scatter. From Figure 8-b, after curing, the average value and the standard deviation of the electrical resistance were $193 \mathrm{ohm}$ and $16 \mathrm{ohm}$, respectively, whereas after carbonation these values shifted to $97 \mathrm{ohm}$ and $13 \mathrm{ohm}$, respectively. The decrease by a 2 factor is rather unexpected as the carbonation process induces a reduction of the porosity. However both values (after fabrication and after carbonation) are of the same order of magnitude (some hundreds) and usually a significant evolution for the reinforced concrete is rather a thousand. Finally, the corrosion rate after curing (Figure 8-c) was below 0.1 $\mu \mathrm{A} / \mathrm{cm}^{2}$ thus indicating a negligible level of corrosion according to Andrade et al. [9]. After carbonation a drastic increase of corrosion rate (values exceeding 10 $\mu \mathrm{A} / \mathrm{cm}^{2}$ ) demonstrated a high level of corrosion [9]. This could be explained by the release of the initially bound chloride ions induced by carbonation.
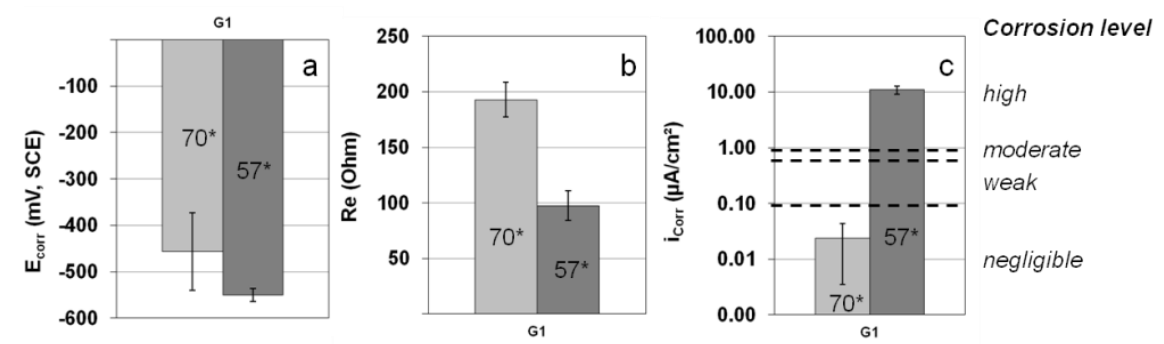

*Amount of specimen characterized

Figure 8. (a) Half-cell potential, (b) resistance and (c) curent density of G1 specimens after curing (light grey) and after carbonation (dark grey). 


\section{Electrochemical Chloride Extraction Treatment}

ECE treatment deals with transformations of corrosion products, extraction of chloride ions, production of hydroxyl ions and migration of ions. This part of the paper aims to study these different issues.

\section{Corrosion products characterization}

Raman spectroscopy. During ECE treatment, regular Raman acquisitions (every day) were performed on a G1 specimen before carbonation to follow the phase transformations induced. After two days of polarization, the main phase detected was magnetite (main Raman band at $670 \mathrm{~cm}^{-1}$ ) (Figure 9). This phase remained stable during 2 weeks of polarization after which the treatment was ended. Further experimentations will be done for a Raman microspectrometry study on a chloridecontaminated specimen which is carbonated.

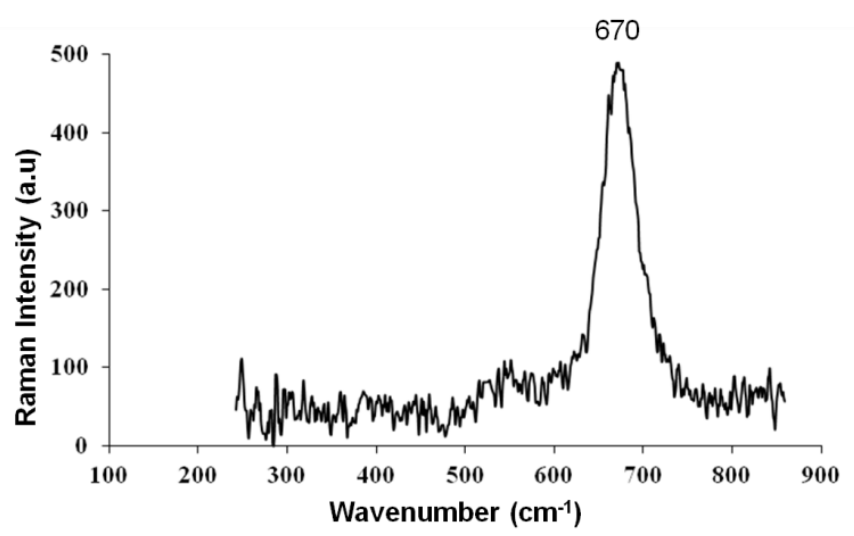

Figure 9. Magnetite Raman spectrum.

Scanning electron microscopy. SEM images after treatment (Figure 10) showed no evolution of the corrosion layer thickness (Figure 10-a) and evidenced a morphological evolution of these corrosion products (Figure 10-b). Elemental analysis allowed verifying the absence of $\mathrm{Cl}$ in the corrosion products composition after treatment (Figure 11). Other elements like $\mathrm{Na}$ and $\mathrm{Al}$ were detected into the corrosion products after treatment. 

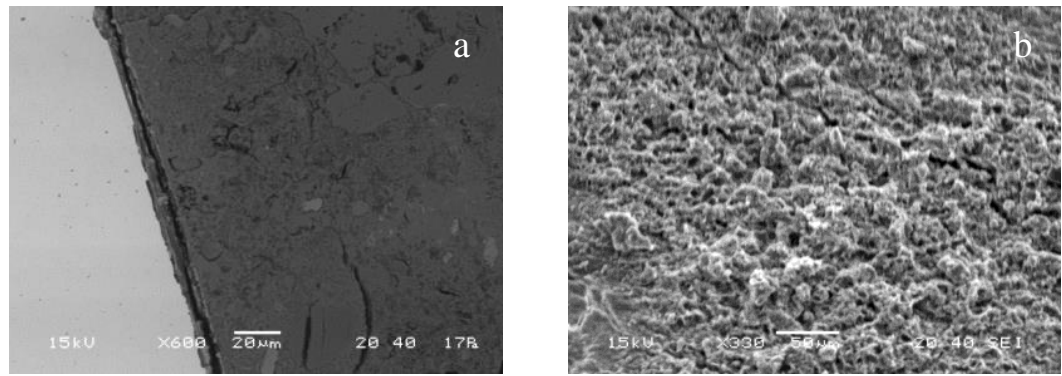

Figure 10. (a) BEIC-SEM image (x600) of the steel/concrete interface on cross section of specimens type G1 after treatment, (b) SEI-SEM images of corrosion products observed into the rebar imprint on fracture after treatment $\mathrm{x} 330$.

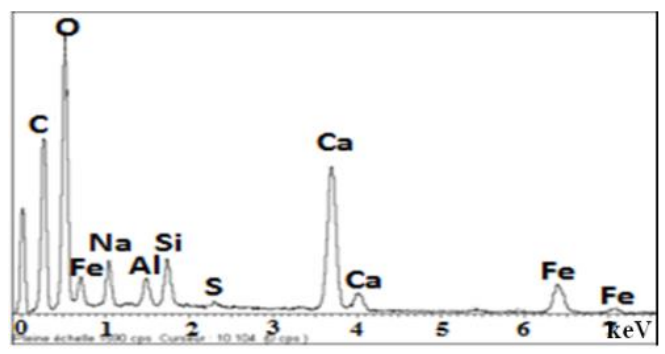

Figure 11. EDS elemental analysis of corrosion products after treatment.

\section{Chloride titration}

Figure 12 shows the evolution of chloride content in the concrete during the ECE treatment. The chloride threshold level for preventing corrosion in new structures as indicated in the EN206 standard [10] is also represented. Before treatment, the total and free chloride content was respectively $1.52 \%$ and $1.35 \%$ for the internal depth and was $0.94 \%$ and $0.94 \%$ for the external depth. These contents different from the $3 \%$ added in the mix were explained by a lixiviation during the curing (28 days in water). After 3, 7, 14 and 28 days of ECE treatment the chloride ions extraction amounted to about 52,67,89 and 92\%, respectively, in the external cover and 27, 70, 92 and 96\%, respectively, in the centimetre around the rebar. The extraction was faster during the first seven days of treatment which is in accordance with literature results [4-7]. Results show that the chloride content became less than $0.4 \%$ by weight of cement after 3-14 days of ECE treatment. Figure 12 also highlights that the difference between total and free chloride ions contents decreased with the duration of treatment which could mean that initially bound chloride ions can be electrochemically extracted. 
For the non-polarized specimens, the chloride content decreased due to lixiviation but was still above $0.4 \%$ by weight of cement around the rebar after 28 days of immersion.

Finally, the results of chloride ions extraction obtained from the concrete and from the electrolyte were in good agreement.

Figure 12 also shows the evolution of alkalinity in the vicinity of the rebar. The observed realkalisation was probably due to production of hydroxyl ions around the rebar and to the migration of cations towards the rebar. Based on the obtained results and the standard [11] concerning realkalisation, the minimum treatment duration required is either 28 days to obtain a $10 \mathrm{~mm}$ realkalised concrete zone around the rebar or a range of 7-14 days considering the experimental rebar diameter $(5 \mathrm{~mm})$.

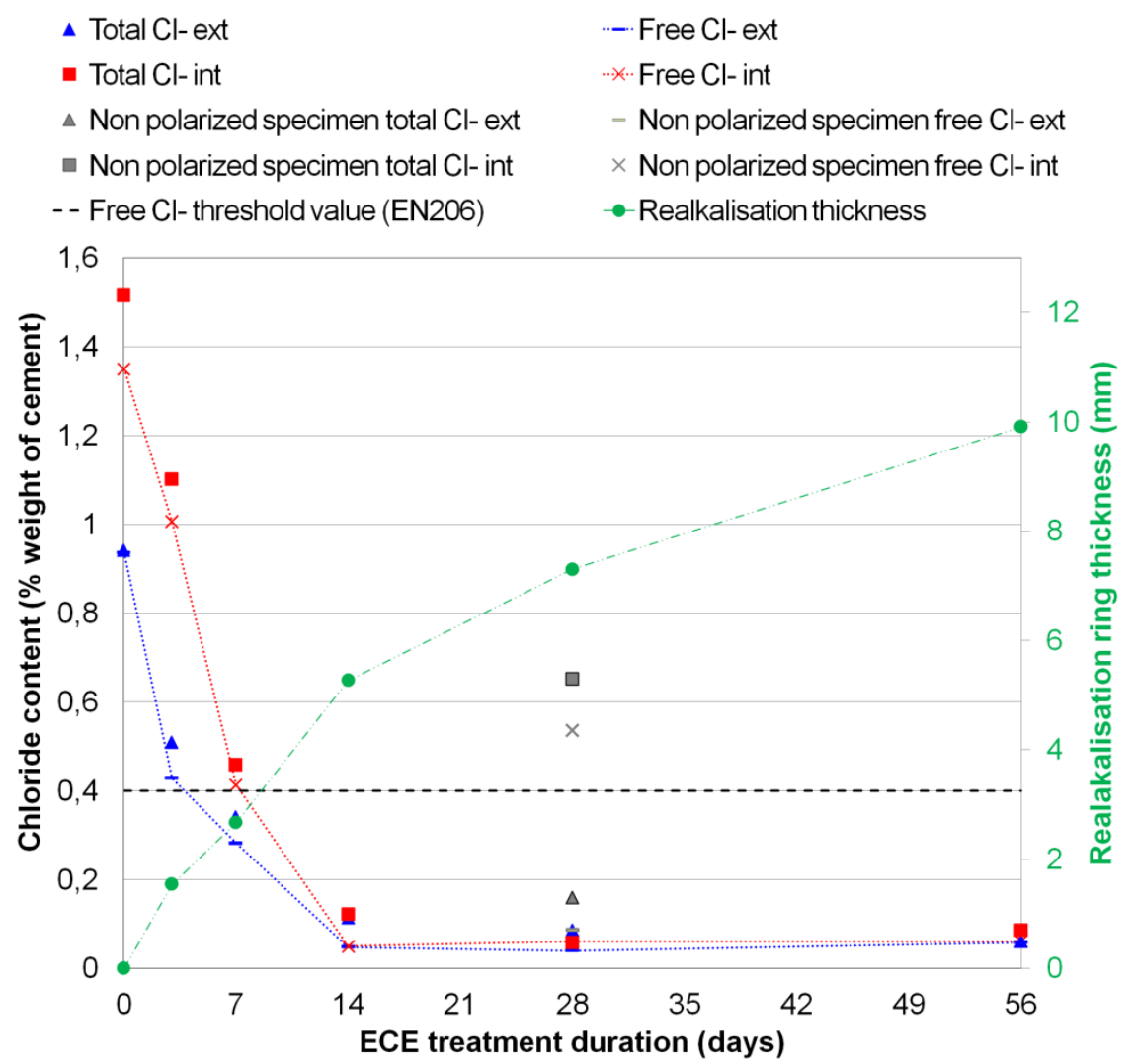

Figure 12. Evolution of chloride content and of the realkalisation ring thickness around the rebar $(\mathrm{pH}>9)$ during ECE treatment. 


\section{Evaluation of the medium-term performance of the ECE treatment}

The durability of the efficiency of the ECE treatment depending on its duration (7, 14, 28 and 56 days) was studied 5, 10 and 15 weeks after the end of treatment (Figure 13), following the corrosion rates of 20 specimens. The first five weeks were necessary for the steel rebars to depolarize after the treatment. Results show that 7 days of treatment $\left(\mathrm{i}_{\text {Corr }}>1 \mu \mathrm{A} / \mathrm{cm}^{2}\right)$ was not sufficient to halt corrosion. In order to obtain a negligible level of the rebar's corrosion rate $\left(i_{\text {Corr }}<0.1 \mu \mathrm{A} / \mathrm{cm}^{2}\right.$ ), a minimum of 14 days appeared to be necessary. This duration is in good agreement with the duration for which the chloride content became less than $0.4 \%$ by weight of cement. Figure 13 also presents the corrosion rates of specimens in immersion for 56 days without current. Comparing the corrosion rates of the samples treated for 56 days $\left(\mathrm{i}_{\text {Corr }}<0.1 \mu \mathrm{A} / \mathrm{cm}^{2}\right)$ and the samples only immersed for 56 days $\left(\mathrm{i}_{\text {Corr }}>1 \mu \mathrm{A} / \mathrm{cm}^{2}\right)$, it appears that the latter are still corroding. This can be explained by the fact that although the chloride ions have been removed during the immersion, the realkalisation has not been performed and therefore corrosion remains active.

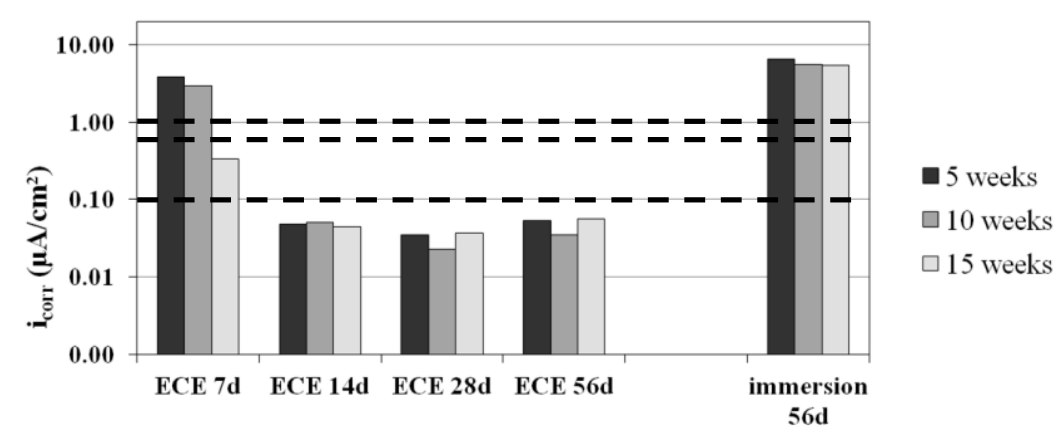

Figure 13. Evolution of corrosion current density for G1 specimens treated (7, 14, 28 and 56 days) and immersed 56 days (non polarized), 5, 10 and 15 weeks after ECE treatment.

\section{Conclusions}

In this experimental work, the set-up designs adopted to study, first the corrosion processes in carbonated and chloride-contaminated reinforced concretes, and second, the electrochemical chloride extraction treatment were presented.

Results obtained on G1 specimens allowed to establish the following conclusions: 
- Chloride-contaminated G1 specimens showed a negligible corrosion level 30 days after curing as indicated by corrosion rates less than $0.1 \mu \mathrm{A} / \mathrm{cm}^{2}$.

- After the carbonation aging, as expected, the corrosion rate increased rather drastically as evidenced by corrosion rates higher than $10 \mu \mathrm{A} / \mathrm{cm}^{2}$. SEM results confirmed this behaviour with the observation of corrosion products on most of the interface (5-20 $\mu \mathrm{m}$ on the rebar and up to $250 \mu \mathrm{m}$ of penetration within the surounding the concrete).

- Efficiency of the electrochemical treatment based on chloride extraction as well as realkalisation of the concrete around the reinforcement was demonstrated. Two weeks of treatment were needed to obtain a free $\mathrm{Cl}^{-}$ content below $0.4 \%$ by weight of cement while 28 days of treatment resulted into one centimeter of realkalisation around the rebar.

- Electrochemical characterizations evidenced a negligible corrosion level $\left(\mathrm{i}_{\text {corr }}<0.1 \mu \mathrm{A} . \mathrm{cm}^{2}\right)$ for a ECE treatment duration longer than 14 days.

- $\quad$ Finally, regarding the durability of the treatment efficiency, after almost 4 months, the corrosion rate remained at a negligible level (no resumption of corrosion).

The durability issue will be further studied by exposure to cycles of relative humidity at $20^{\circ} \mathrm{C}$ (1 week $92 \% \mathrm{RH} / 2$ weeks $\left.60 \% \mathrm{RH}\right)$ by means of electrochemical characterizations. Comparison with the 3 other series will give a larger view on this subject.

\section{References}

[1] Tissier, Y., Bouteiller, V., Marie Victoire, E., Joiret, S., Chaussadent, T. (2016), Corrosion processes and ECE treatment in a both carbonated and chlorinated reinforced concrete, Materials Systems and Structures in Civil Engineering Conference, 21-24, August 2016, Lingby, Denmark.

[2] Tong, YY. (2009), Traitement électrochimique de réalcalinisation pour la réparation du béton armé dégradé par carbonatation, $\mathrm{PhD}$ thesis, Université Pierre et Marie Curie France.

[3] CEN/TS 14038-2 (2011), Electrochemical realkalisation and chloride extraction treatments for reinforced concrete - Part2: chloride extraction.

[4] Orellan Herrera, J.C., Escadeillas, G., and Arliguie, G. (2006), Electrochemical chloride extraction: Influence of C3A of the cement on treatment efficiency, Cement and Concrete Research, vol 36, pp. 1939-1946.

[5] Swamy, R.N. and McHugh, S. (2006), Effectiveness and structural implications of electrochemical chloride extraction from reinforced concrete beams, Cement and Concrete Composites, vol 28, pp. 722-733.

[6] Fajardo, G., Escadeillas, G., and Arliguie, G. (2006), Electrochemical chloride extraction (ECE) from steel-reinforced concrete specimens contaminated by "artificial" sea-water, Corrosion Science, vol 48, pp. 110125 . 
[7] Arya, C., Sa'id-Shawqi, Q. and Vassie, P.R.W. (1996), Factors influencing electrochemical removal of chloride from concrete. Cement and Concrete Research, vol 26, pp. 851-860.

[8] Boucherit, N., Hugot-Le Goff, A and Joiret, S. (1991), Raman studies of corrosion films grown on $\mathrm{Fe}$ and $\mathrm{Fe}-6 \mathrm{Mo}$ in pitting conditions, Corrosion Science, vol 32, pp .497-507.

[9] C. Andrade and C. Alonso, "Rilem TC 154-EMC Test methods for on-site corrosion rate measurement of steel reinforcement in concrete by means of the polarization resistance method" Materials and Structures, 37 (2004) pp.623-643.

[10] EN 206 (2014), Concrete - Specification, performance, production and conformity.

[11] EN 14038-1 (2016), Electrochemical realkalisation and chloride extraction treatments for reinforced concrete Part1: Realkalisation. 